\title{
CRITICAL DISCOURSE ANALYSIS OF TAMIL CULTURAL IDENTITY IN CELEBRITY ENDORSEMENT IN ADVERTISEMENTS
}

\author{
Shivany,S \\ University of Jaffna. \\ shanshivany@yahoo.com
}

\begin{abstract}
This study examined printed image advertisements in Jaffna market from a Critical Discourse Analysis perspective. This study mainly focused on the Tamil cultural identity in celebrity endorsements employed by advertisers to influence their customers. The analysis is based on Fairclough's three-dimensional framework. It demonstrates how the ideology of 'cultural identity' is produced and reproduced through advertisements in popular printed advertisement materials. A qualitative research was conducted on 15 newspaper advertisements. Findings indicated that advertisers used various strategies to reach the consumers through cultural identity. The advertisements, which promote Tamil cultural identity, norms and influence customers to a certain extent into believing whatever that is advertised is undeniably true. This study revealed that the Tamil cultural identity was considered as an advertising strategy by few producers for positioning their products. Findings showed that cultural celebrity commendations are advertising language used to switch consumers' minds. Thus advertisers use celebrity commendations as a means to exercise control over the unique culture, but it can be seen in few advertisements, but it is recommended that the producers and providers of services should consider the celebrity features, which set with the culture of the consumer, to whom the company targets.
\end{abstract}

Keywords: Critical discourse analysis, cultural endorsement, Tamil cultural identity,

\section{INTRODUCTION}

Marketing managers are looking for celebrities to give companies a better chance of communicating their message to consumers. Many companies using celebrity endorsement as widely and acceptable tool for reaching customers all over the world. In
Sri Lanka many marketers use this method to penetrate the market to have more market share.

Celebrity endorser as any individual who relishes public credit and who uses recognition on behalf of a consumer good by appearing with it in an advertisement. In 
today's media cluttered environment where it is difficult to grab consumer's attention. Celebrities develop a persona through the type of roles they play in society as well as how they are portrayed in the media. When celebrities endorse a product, the meaning developed around a particular celebrity will transfer to a company, brand, or product.

Use of celebrities for endorsement, not all celebrity endorsements have been successful. Consumers are not able to identify with some celebrity advertisements. Consumers do not comprehend the set of the celebrities in the advertisements. The list of ineffective examples suggest that it will be wrong to consider celebrity endorsement which have some ineffective responses with the customers and the market. In order to enhance the effectiveness of celebrities, it has been suggested that marketers need to establish the link among the product, celebrity, and consumer culture by considering the type of product. Therefore, it is more important to have some operative endorsements to transfer the message through celebrity endorsers to a selected consumer group.

In northern Sri Lanka, where the context is enriched with the Tamil culture, to whom the companies target to market their products. Effective celebrity endorsements should possess the Tamil cultural unique identities to transfer the value to the customers. This study is intended to identify whether the advertisements hold celebrity endorsers have the Tamil cultural identities. Journal of Business Studies

\section{RESEARCH PROBLEM}

Celebrity-endorsed ads were most often related to the values of quality/effectiveness, success/status, beauty/youth, and enjoyment/leisure. Celebrity gender and age were stereo typically associated with specific cultural values, which imply that celebrity endorsers are not treated inversely from the other types of endorsers in terms of gender and age when advertising messages are created (Elberse \& Verleun, 2012).

Sri Lankan Tamils are culturally and linguistically distinct, Genetic studies indicate that Tamils are closely related to other ethnic groups in the island while being related to the Indian Tamils from South India and Bengalis from the Northeast India as well (Kshatriya, 1995).

Sri Lankan Tamils developed their culture in relative isolation from the great cultural centers of southern India. For centuries, Sri Lankan Tamils appear to have interacted more closely with their southern compatriots, the predominantly Buddhist Sinhalese, than with southern Indians; apart from language and religious affiliation, Sri Lankan Tamil and Sinhalese social systems, customs, and folk religious practices resemble each other far more closely than either does to the cultures of neighboring India. The Sri Lankan Tamils' unique geographical and historical experience generated a distinctively Sri Lankan variant of Tamil culture. A fact that is keenly felt by Sri Lankan Tamils themselves, who often 
speak of themselves as a small, unique, community.

The center of Sri Lankan Tamil population and culture is the densely populated Jaffna Peninsula of the extreme north; other Tamil population concentrations are found on the island of Mannar and along the eastern coastal littoral, stretching from north of Trincomalee to Batticaloa. Many of today's Sri Lankan Tamils refer to their traditional Northern and Eastern Province homelands.

There are many changes we could observe, in Northern Sri Lanka after 2009, end of war paves the way to encourage many investors. Not only the south investors but also investors from other countries, entered into northern market. To attract the consumers in the Northern province, they tried many marketing strategies. Advertising is a marketing communication methods, which are used by those marketers and investors, in Northern province. They involved in celebrity endorsement advertisements in different media to attract people, but whether the marketers have reached the objectives is questionable. Studies showed that cultural identity in advertisements are accepted by the particular culture, to whom the advertisements target. This study intends to show whether the celebrity endorsement advertisements posted by the marketers in the Northern province, have included Tamil cultural identity in celebrity endorsement advertisements.
The meaning transfer model, proposed by McCracken (1989), emphasizes the important role that cultural meanings play in the process of messages passing from a celebrity to a product and from a product to a consumer. According to the model, each celebrity has a unique set of meanings, which derive from the type of person he or she is, the specific cultural contexts he or she comes from, the roles he or she has played, and the stories that have developed around him or her (Tellis, 2004).

In many countries celebrity endorsers are very match with the culture of the consumers. In Indian Tamil cultural consumers are attracted with the special endorsement advertisements. but, in Sri Lanka even the Tamil consumers are targeted by the foreign marketers, whether they are attracted by cultural specific celebrity endorsements.

\section{Research gap}

Brand equity and celebrity endorsement have been studies by the researchers in Northern province (Sivesan, 2013), Dissanayake, and Ismail, (2015), studied the celebrity endorsement and brand attitude. Ravindra Dissanayake, (2015), studied the factors Determine the Customer-Celebrity Relationship towards Perceived Celebrity Endorsements in Sri Lankan Services Sector. Thusyanthy \& Tharanikaran, (2015) studied The Relationship Variables to Celebrity Endorsement and Brand Equity. Celebrity endorsement and product harm crisis management was studied by 
Chandima, and Ping Qing, (2015). Tehseen, and Hameed (2015) studied the celebrity endorsement in conflating beauty adverts through a feministic perspective. But present study fills the gaps in critical discourse analysis of Tamil cultural identity in celebrity endorsement in newspaper advertisements.

\section{RESEARCH QUESTION}

RQ: what are the Tamil cultural identities in celebrity endorsement advertisements in newspaper advertisements.

\section{RESEARCH OBJECTIVES}

1. To study textual representations in celebrity endorsement advertisements.

2. To study the Discursive practice of the celebrity endorsement advertisements

3. To identify the Tamil cultural identities in celebrity endorsement advertisements in newspaper advertisements.

4. To suggest the strategies to attract the Tamil consumers through celebrity endorsement modifications.

\section{LITERATURE REVIEW}

The celebrity endorsement, as a potentially effective advertising strategy, can simplify the process by which the audience interprets an advertising message. Each celebrity possesses a unique set of cultural meanings and can bring the meanings into the product he or she is promoting (McCracken, 1989). In this way, the celebrity can help greatly narrow down the thematic dimensions of meanings related to the product (Langmeyer Journal of Business Studies
\& Walker, 1991). Previous literature focuses on use of celebrity endorsers, it is widely accepted that celebrity endorsers are more effective than non-celebrity endorsers in generating all desirable outcomes (attitudes towards advertising and endorsed brand, intentions to purchase, and actual sales) when companies utilize celebrities whose public persona set with the products and target audiences (Erdogan, 1999).

Culture has long been believed to be the force that influences people in a society to follow the norms of their collective identity. Kroebar and Parsons (1958) defined culture as "transmitted and created content and pattern of values, ideas, and other symbolicmeaningful systems as factors in shaping of human behavior and the artifacts produced through behavior". A similar definition was given by Taylor (1964) in which culture is defined as that complex whole which includes knowledge, belief, art, morals, law, custom and any other capabilities and habits acquired by man as member of society. Hofstede (1980) treated culture as the collective programming of the mind that distinguishes the members of one group or category of people from another. He defined culture as the interactive aggregate of common characteristics that influence a human group's response to its environment. Sojka and Tansuhaj (1995) conducted a review of twenty years of cross-cultural research and provided their definition of culture as a dynamic set of socially acquired behavior patterns and meanings common to members of a particular society or human 
group, including the key elements of language, artifacts, beliefs and values.

The above-mentioned definitions imply that culture presupposes a collectivity and the word can be applied to any human collectivity or category. This study applies the theory of them to find the cultural uniqueness of Tamil culture living in Sri Lanka. Culture has to do with shared ideas, the way a group of people conceptualize and represent the world and life to themselves, thus differentiating people of one society from another. The word "culture" is usually reserved for societies and it has been operationalized as nations or as ethnic or regional groups within or across nations (Hofstede, 2001). Schwartz (1999) stated that national boundaries do not necessarily correspond to the boundaries of organically developed, relatively homogeneous societies with a shared culture but there are strong forces towards integration that can produce substantial sharing of culture in nations that have existed for some time. A country's culturehas long been identified as a key environmental characteristic underlying systematic differences in consumer behavior; cultural norms and beliefs are powerful forces shaping people's perceptions, dispositions, and behaviors (Markus \& Kitayama, 1991).

While culture can never be treated as a single independent variable, for it is a loaded and complex variable, overarching many areas in life (Christie, Kwon, Syoeberl, \& Baumhart, 2003) and culture includes an Journal of Business Studies extensive number of dimensions and values, much of the, research on culture is concerned about understanding cultural values i.e. shared beliefs about how people should behave. There have been a number of studies to identify core values across societies, and those values that differ between societies and are a result of local cultural differences (Burton, 2009).

One of the earliest attempt toward proposing cultural categories for analyzing culture came, from Kluckhohn and Strodt beck (1961). They proposed six cultural dimensions namely the nature of people, the person's relationship to nature, the person's relationship to others, the modality of human activity, temporal focus of human activity, and conception of space.

Hofstede (1980) presented one of the first empirically validated typology of culture across different nations. He identified four dimensions of culture on which a country's culture could be placed. He named them as power distance, uncertainty avoidance, individualism-collectivism, and masculinity-femininity. Later, based on the work done by Michael Bond(1988), Hofstede (1980), added a new dimension of long-term versus short-term orientation to extend the number of dimensions to five.

\section{FAIR CLOUGH CRITICAL DISCOURSE ANALYSIS (CDA) MODEL}

Fair clough $(1989,1995)$ gave his model for 
CDA analysis and this model consists of three dimensions all these dimensions are interrelated with each other.

a. The target of analysis (visual, verbal and visual texts)

b. The methodology on the basis of which we can receive and produce text (viewing/speaking/listening/writing/ reading/designing) by creature aspect.

c. All the conditions which are the key aspects of the socio-historical conditions and carry out these formations.

Faircolough gave three aspects to critically analyze any text

a. Text analysis (description)

b. Processing analysis(interpretation)

c. Social analysis (explanation).

Chouliaraki \& Faiclough (1999) said that the communicative interaction according to the CDA shows the linguistics and semiotic features on conversations and interactions that how they are systematically connected with one another and what's going on linguistically or thematically in a Society Fairclough's three dimensional model of analysis is very much useful not only in linguistics, but also in other fields like semiotics and so many other disciplines if we want to critically analyze any text either its spoken or written Fairclough (1992). three experimental stages are linked to discourse definition. He said in his model that all languages are part of social practice. He also locates three dimensions on the basis of which he operates Language as a discourse. Margret (2005) use Fairclough Journal of Business Studies approach of CDA to analyzing English as a second Language. He said that availability of and access to linguistic resources is part of a person's political economy which means that the analysis of ESL (English as secondary Language) texts lies well within the purview ofCDA.

\section{METHODOLOGY}

Fairclough's 3-D model of Discourse Analysis is applied to analyze the 15 selected advertisements. Each advertisement has been analyzed on textual, discursive and cultural level. A qualitative research design was adopted which seeks to investigate how discourse in advertisement involves people in constructing meaning of culture. Data collection was done on 15 commercial advertisements and each advertisement was analyzed at text (Micro level), discursive practice (Meso level), socio-cultural practice (Macro level).

\section{DATAANALYSIS}

Figure 1: Critical Discourse Analysis model

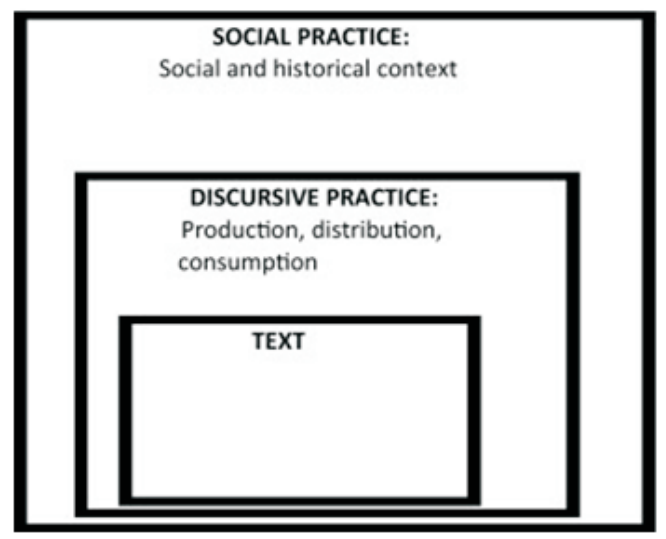

Source :Faircolough $(1989,1995)$ 


\section{Advertisement 1}

Advertisement for saving account Textual analysis

It is an advertisement to promote saving at banks, it expresses the messages, that gifts for savings offered to kids. Further this advertisement conveys the messages to the parents, as well as the children who are interested to get gifts from the bank. This advertisement posted during the new year festival period. Bank motivates the customers to have more money in the children accounts on or after the new year festival.

\section{Discursive practice}

This advertisement links the traditional event, this advertisement attracts the children and parents through the joyfulness from the children perspectives and their happiness during festivals.

Social practice (cultural identity conveyed by the celebrity endorsement)

In Tamil culture new year festival is an important centenary to them. Children always receive grand money gift from their parents, grandparents, relatives, and from the teachers. End of the year festival they would have much money in their pockets. Giving money to the children during the new year festival time is a regulated occasion to Tamil people. Banks encourage this event and motivate the customers, as children to save those monies into their savings accounts. Bank also gives dices as gifts to play with siblings during their leisure time, dice which is an instrument played by the children in Tamil culture traditionally.

Celebrities in the advertisements are set with the Tamil culture, the way kids are playing closely related to the culture, the mat they sit on, the background table and the belongings on the tables, traditional sweets on the table, and playing dices are faithfully related to the Tamil culture, but the girl child did not wear the traditional ornaments wore by girl babies in Tamil culture would give more closely related to the culture (wearing flowers, "pottu", jewelers)

\section{Advertisement 2}

Advertisement for banking service

\section{Textual analysis}

This advertisement was developed by the Bank of Ceylon Sri Lanka. This advertisement informs the customers, about the bank holiday on the new year day. Next to the new year festival day banks invites the customers to join with the bank for getting gifts for the children, and they wish the customers for enjoying the new year festival at home with the 
family on the celebration day.

\section{Discursive practice}

In Tamil culture people always celebrate the new year festival very magnificent. They spend their time with the family and relations. They go to temple and share the sweets with family and friends. If the bank offers any gifts to open new accounts for their kids on that day it gives difficult them to go to the bank and spend time for banking services, then they loss their happiness at home, therefore bank invites the customers, next day after the occasions. Then the customers can do their banking services separately.

\section{Social practice (cultural identity} conveyed by the celebrity endorsement) Celebrities used to convey the messages to the customers are really set with the Tamil culture. celebrities, their dress code, their positions on the advertisements, facial expressions, their culture, how the grandparents treat the kids in the home, kid celebrities, way of dressing, everything perfectly set with the Tamil culture. This advertisement, overall perfectly set with the Tamil culture and specially designed for the Tamil customers, in the Northern market.

\section{Advertisement 3}

This advertisement was developed by the peoples bank Sri Lanka to promote the customers to have more money in female Account Branded "Vinita Vasana"

\section{Textual analysis}

This advertisement targets the women who have "vanithavasana" accounts at peoples bank branches. This advertisement informs the account holders, that who have the remarkable balance in the account can earn many products gift, bonus interest rate, credit card without any payments.

\section{Discursive practice}

This advertisement targets the Tamil women in Northern Sri Lanka. It explains the maximum benefits by keeping the balance in the bank account. It promotes the women to be a smarter lady. it passes the messages to the women to save more money for their secure life in future.

Social practice (cultural identity conveyed by the celebrity endorsement) Even if the advertisement target on the women in Tamil culture the celebrity endorsement in the advertisements is not set with the Tamil women. The bank targets the working and non-working women, who have the vanithavasana account, and who needs the home 
equipment. Celebrity in the advertisement only reflects the adults age, and not set with the facial beauty of Tamil culture.

\section{Advertisement 4}

This is an advertisement from a jewelers shop, which promote rich purchase of golden jewels from the shop on the famous Tamil occasion "Ashaya Trithiya"

\section{Textual analysis}

Discounts are given to the customers cost of Jewels, with the cost of labor charge of making the jewels customers can purchase the jewels from the shop, and they can get prizes for every purchase. Customers can make advance booking for that special day.

\section{Discursive practice}

In Tamil culture specially Hindus they wear many jewels. Wearing golden jewels and having golden jewels always give happiness and prestigious to them. This advertisement expresses the message, that purchasing a golden jewel on the Ashaya Trithiya" gives more happiness and richness in their life in future. This advertisement targets the women, who purchase the jewel on that day and the others, who purchase jewel for women. The messages conveyed in the advertisement strongly suggest the target group to have a golden jewel on that occasion will give more and more prosperity to them and their families.

Social practice (cultural identity conveyed by the celebrity endorsement) This advertisement specially targets the Tamil people, who have a positive attitude towards having golden jewels on "Ashaya Trithiya". The celebrity in this advertisement is very much supported the culture of Tamil. Her dress code facial expression, beauty, make-ups, jewels are wearing, the way she wore the saree, flowers, smile of the celebrity, hairstyle everything is in the perfect manner. Therefore, this advertisement very much attracts the people, to whom the advertisement was posted.

\section{Advertisement 5}

This advertisement is related to a leasing services offered by a bank.

\section{Textual analysis}

This advertisement says the relationship between the bank and the customers who get leasing facilities from that bank. The bank promises mutual relationship they have with the customers in leasing. This advertisement is indent to motivate the customers to join, with the bank to buy vehicles through leasing scheme. 


\section{Discursive practice}

People who do leasing with banks always fear of payment schemes. It expresses the flexible scheme, payment system for leasing vehicles to families. The message expresses the extra ordinary facilities given by the bank for lease than the other commercial banks in Sri Lanka. No of leasing and the amount leased are highest than compare to other banks. They are the first mover in leasing services and decided to enhance the number of leasing customers soon. Compare to other private commercial banks, thy have the customized services offerings to the leasing customers. To enhance the life quality of the customer they would try to offer many value added services to the customers. They offer an innovative service solution for their customers because they have inimitable relationship with their customers rather than in a transaction platform.

Social practice (cultural identity conveyed by the celebrity endorsement) This advertisement conveys the messages in Tamil language, to target the Tamil consumers in Northern province. Mother Celebrity played as a mother in the advertisements is not set with the Tamil culture, to whom the advertisement targets. Dress code, way pf dressing, hairstyle all are different from the Tamil culture. celebrities, played as roles of father is set with the Tamil culture, the kid in the advertisement does not express the Tamil culture as well. In Tamil culture, usually the families have minimum two children, with their grandparents. So the celebrity endorsements expressed in the advertisements are not set with the Tamil culture.

\section{Advertisement 6}

This advertisement related to mobile service charges as postpaid scheme.

\section{Textual analysis}

It expresses the voice, data, and SMS can be experienced into one service package. It conveys a payment scheme for the mobile service users, who prefer to pay in a post method. It invites the customers to design their payment scheme themselves based on the available plan on the package. It consisted of different units based on the minute payment, payment for seconds and based on the usage pattern of the customer, they can decide the payment scheme or based on the needs of the customer they can decide the charge for their services. It totally expresses the flexible payment scheme for the customers who, have an eventual need for mobile service. This service lets the customer to talk more freely and pay more in future. 


\section{Discursive practice}

Customer who needs unlimited talking time with their friends and lovers can freely talk any time whenever they need to take a call. This advertisement conveys a message to the adult groups for free nonstop conversation and chatting among them. Adults are very happy while enjoying the packages from the service providers. Celebrities pass the message that they are really happy by enjoying the flexible payment scheme from the service offer.

Social practice (cultural identity conveyed by the celebrity endorsement) Messages which are designed to convey to the customers are in Tamil language, therefore the organization targets Tamil people for the service through this advertisement. Celebrities in the advertisements are adults (working or studying not clear may be studying is more appropriate). Three boy celebrities who set with boys in Tamil culture. The girl celebrity in the advertisement is not set with the girls in Tamil culture. In Tamil culture standing girls with the boys very closely are not acceptable. Dress code is set with the adult girl in Tamil culture but, having 'pottu', some acceptable dress code may attract the Tamil culture more. Let the adults talk more and pay more sometime create the parents a negative attitude towards the service. This advertisement messages target all customer type in Tamil culture, therefore having celebrities to convey the message to Tamil celebrative, or celebrative made-up with Tamil features would be more attractive.

\section{Advertisement 7}

It is an advertisement to promote roofing sheets.

\section{Textual analysis}

This advertisement expresses strong and durability, and the viability of the roofing sheets. The company introduces the color roofing sheets for the customer preferences whatever they have.

\section{Discursive practice}

This advertisement posts a message to the customers through the advertisement is the durability of the roofing sheets in a long life, and it expresses the corrective decision making by the carpenter. It expresses the sanctuary, protection and quality of the traditional roofing sheets. customers admire the shapes and colors and the style of the product.

Social practice (cultural identity conveyed by the celebrity endorsement) Celebrities in the advertisement plays the grandparent roles, carpenter role, 
kids, and housewives. There are three celebrity endorsements in the advertisements, one endorsements explain the traditional value of the Tamil culture how the grandparents secure their children in a family, and the company compares the safeguards from grandparents' love with the safety of the roofing sheets. The second celebrity endorsement expresses the son's responsivity in securing his father, this is also a powerful value in the Tamil culture, respecting parents and look after them in their old age are the essential desires of the son or in the family. This company bears the message to the customers about the shelter roofing sheet through the way how the parental safeguard is guaranteed by his son.

The celebrity endorsements in the third section in the advertisements, there are carpenter and the housewives. Carpenter is set the Tamil culture, but the dress code expresses as the professional way of doing carpentry works. And the women standing beside the carpenter and looking through the beauty and the excellence of the roofing works are set with the Tamil culture. The dress code and the facials are set with the culture but there should be pottu on their face would be more attractive and more unique for the Tamil culture itself.

\section{Advertisement 8}

This is an advertisement to promote the sales of wet grinder.

\section{Textual analysis}

This advertisement articulates the benefits of wet grinder, and its free offer (Idly steamer). It messages to the target customers(women), about the easiness of the wet grinder. The texts on the advertisement in the big font says the painless work in the kitchen, load for housewives and the working women. The works in red color font highlights the features of the product as the high quality grinding stones, high power force motor, easy to place on table, making the dove as a base for Roddi, pizza, role ect. The red backgrounded brand posts the message about the brand as it is a brand, which gives prestige to home makers. It says the trust and assurance through the well-known trademark in Northern province.

\section{Discursive practice}

Through this advertisement the company wants to inform the authorized dealers for sales of the particular brand. Through the celebrity endorsement. This advertisement carries the happiness of the homemakers by having this grinder in their homes. 
Social practice (cultural identity conveyed by the celebrity endorsement) Celebrity endorsement in this advertisement perfectly set with the Tamil culture. Dressing code, way of dressing, color, the jewels she wore, pottu, facial look, and even the hairstyle also set with the Tamil culture. In Tamil culture home makers traditionally cook the idly, thodai, vadai, and Appam in their daily needs as well as for their functions. They use the traditional equipment for making the mixer for this foods. This grinder reduces the workload of the home makers and help to prepare the meals whatever they need. This advertisement carries a boost to make those traditional foods through the base mixer produced from the grinder.

\section{Advertisement 9}

This advertisement is to promote the sales of children milk powder.

\section{Textual analysis}

Texts in the advertisement couriers to the mothers, that the milk power encourage the brain development of the child. in the dark blue color with big font size, it stresses the child's brain activation through this milk power. The texts on the advertisement is small fonts tells the needed nutrients to the children from 1-4 years old. This milk powder gives the full nutrients to the children they need to grow for their growth.

\section{Discursive practice}

Through the celebrity endorsement this advertisement tries to tell the mothers about the active and learning capacity form the milk powder and how the child quickly learn from his childhood. If they don't have enough nutritional components from their food and milk, it leads to slow the brain development of a child. Position in the advertisement let the mothers to dream on his child to grow up quickly.

Social practice (cultural identity conveyed by the celebrity endorsement). In Tamil culture mother prefer to Brest feed the child. Breast feeding is the traditional way Tamil mothers favor to grow their children. In Tamil culture a family system has five children and more than that, mother feed all the child and she takes traditional and healthy, natural food, then she feed the child, therefore the child and mother both are rich in health and it fasts brain development. Mothers are advised to feed the child, in Tamil culture pregnancy, delivery time, and during feeding period, mothers are treated with aa special care, with natural medicines, these intakes to mother boost more breast feeding to the child. Child 
grew up and be a smarter and active. This advertisement encourages the bottle feeding against the Tamil culture.

Celebrities in this advertisement are not set with the Tamil culture, the child and the mother both are really not tie with the culture, it expresses the western ethos. It leads the mothers to be a western mother as stopping Brest feeding and to shift to bottle feeding.

\section{Advertisement 10}

This is an advertisement targets the micro, small and medium level entrepreneurs in Northern province.

\section{Textual analysis}

Texts in the advertisement give many messages to Small, Medium, and Micro level entrepreneurs, who needs loan services. There is a text in big font size "this is for you, who intend to win the world through self-employment". This advertisement targets a special segment MSMEs. At different interest rate many loan services are introduced by the bank. In the separate boxes with diverse colors brand names for the different loan schemes are specified, it clearly shows the loan scheme, advisory services, selfemployment development loan, shortterm farmer loan, diary production loan, loan advisory services, investment loan, advisory service on self-employment, and, farmer loan scheme.

\section{Discursive practice}

This advertisement expresses the concern of banks towards the MSME development in Northern province. Banks tries to convey the message that they secure the special MSME segment for their great success in near future. Small and medium level entrepreneurs do their self-enthusiasm towards the livelihood activities and for the success in market development. They have handcraft work, gardening materials, plants, jewelling, coconut crafts, small scale farming, and gardening. This MSMEs have many financial struggles to survive in their industry, they need helps from banks, and other financial organizations. They need a special loan scheme for different purposes. Therefore, this bank targets them separately, as a special segment for their success and survival.

Social practice (cultural identity conveyed by the celebrity endorsement). There are two celebrity endorsements in this advertisement. The bank's target group is MSMEs in Northern province. the celebrities, who play the roles as MSMEs in the advertisement are not set with the actual MSMEs in Northern 
province. the celebrity, who plays the role as the welder in the advertisement looks more professional. The women also express the western ethos.

\section{Advertisement 11}

This advertisement related to the insurance services specially to women.

\section{Textual analysis}

This advertisement rich in texts. Content is very high. in the big font size, highlighted the ability to move on to the future life. It confirms that everyone can succeed in their life. This advertisement targets women in Northern market. The words tell the customers a story about a woman who won in her life. She faced many challenges in her life. This insurance company supports the women to face that challenges. She was a teacher with minimum salary as a government servant, and could manage the expenses and the expected targets with the help of the company. Now she is in a position of a leader who leads many women like her.

\section{Discursive practice}

Through the celebrity endorsement in the advertisement, the insurance company transports a posts to the women in the Northern market, that the company supports the women to overcome their financial burden in their work and family life. The celebrity from Tamil culture share her experience with the company, and she signed her words as true and the awards she won. She expresses that she achieved a great success in her life, with the company's support. It is a hidden advertisement, the service offered by the company is purposefully hide by the company to create an interest to make awareness about the company.

Social practice (cultural identity conveyed by the celebrity endorsement) The celebrity endorsement used in the advertisement very much set with the Tamil culture, her happiness, dress code, way of dressing, the "dot" on the face, jewels everything set with the Tamil culture. This celebrity transforms the message very perfectly to the target customers. The celebrity invites the customers to share her story in the website of the company.

\section{Advertisement 12}

It is advertisement to promote the sales of herbal soap.

\section{Textual analysis}

Texts in the advertisement expresses the natural sharpness, and it great gift to human. This product consisted of 18 natural herbal ingredients to secure the human body from micro infections. It 
tells the benefits of the products, and how the product secure human skin from rash, itch, pimples. It delivers a messages that the sales reach a high remarkable point in international march market. It depicts a message that $100 \mathrm{~g}$ only for 50Rs, which can reduce the skin problem easier.

\section{Discursive practice}

Through the celebrity endorsement this advertisement, motive the family members to purchase by shifting from other soaps. This Ayurveda soap with 18 herbs gives the medical treatment to the family members in the family including children. This product gives gift to human being as a nice, clean, sickness free life, smart, and happy movements. White dress expresses the cleanness and purity in family movements. The celebrities in the advertisement give a message to the consumers about the benefits of the soap, and their happiest movement in their life.

Social practice(cultural identity conveyed by the celebrity endorsement) Celebrity endorsements in the advertisement are not set with the Tamil culture. They express the western ethos. In Tamil culture especially Hindu avoids to wear white dress, but in other culture they prefer. But if the advertisement targets the Tamil cultural consumers, the dress code, way of dressing, color, are not set with the Tamil culture.

\section{Advertisement 13}

This advertisement promotes a brand of gas for household purpose.

\section{Textual analysis}

In the big text, the advertisement tells the long use of gas for household purpose. it differentiates the prices in two different packaging. It links the awards won by the company, and the standard mark SLS (Sri Lankan Standard). It goes up to 31 days' consumption, fastest sales growth, and quick moving brand in Island.

\section{Discursive practice}

Through the celebrity endorsement, this advertisement conveys a message that the long days' consumption leads happiness of the home maker. Celebrity tells the customers to shift this brand, because of the extended usage of the product, which give cash savings.

Social practice (cultural identity conveyed by the celebrity endorsement) Celebrity endorsement in the advertisement perfectly set with the Tamil culture. Dress code, way of dressing, jewels, makeup, flower, hair dress, color, facial expression are set 
with the Tamil culture. In Tamil culture home makers always think of savings and elongated consumption, and to prefer to manage their kitchen work within a limited source. Then this celebrity easily attracts the target customers. Wording in the big fond size give different meaning, the additional last letter in Tamil may be deleted.

\section{Advertisement 14}

This advertisement is to promote the sales of three wheelers.

\section{Textual analysis}

The texts in the advertisement expresses the three wheeler as a family vehicle as savers of money. Prestigious, fuel efficiency, cost effective mechanical maintenance, special features, and as the family vehicles for earning and self uses. In the textual context, special features of the engine, internal features, vehicle shape and features of the engine are described in detail. Every product features are clearly described in a point format. It gives a clear picture about the product to the user. Special strength, long term usage, special savings, special security, and convenience are symbolically articulated in an attractive manner.

\section{Discursive practice}

In this advertisements celebrity endorsements are used to convey the message of happiness and family comfortable with the vehicle. The celebrities tell the happiness to the customers, and promote the families to purchase the vehicle for their family use and for business.

Social practice (cultural identity conveyed by the celebrity endorsement). Celebrities in the advertisements are very much set with the Tamil culture, the faces of the celebrities, dress code, kid celebrity, way of dressing color, facial expression, dot on the women celebrity's face, dot on the kids face, temple rope on the men celebrity's hand all set the Tamil culture.

\section{Advertisement 15}

It is an advertisement to convey the message of fuel efficacy of motor vehicle.

\section{Textual analysis}

Texts in the advertisement says the true story of a customer who newly purchased a motor bike with fuel efficiency. The user says that before purchasing he never belief the attributes related to the vehicles, but after the experienced, he really admired from the usage and the mileages of the vehicles. 


\section{Discursive practice}

Through the celebrity endorsement this advertisement encourages new users to purchase the particular brand which has the special features. Sharing the experience of the celebrity, this advertisement tries to canvas others to faith the features of the vehicle.
Social practice(cultural identity conveyed by the celebrity endorsement)

Celebrity endorsement in the advertisement very much set with the Tamil culture, the company selected the Tamil celebrity to share the experience with the other new users in Northern market.

Table 1: Critical Discourse Analysis of Celebrity endorsement advertisements

\begin{tabular}{|c|c|c|c|}
\hline Ad & Textual analysis & $\begin{array}{l}\text { Discursive } \\
\text { Practices }\end{array}$ & Social practices (Cultural identities \\
\hline 1 & $\begin{array}{l}\text { Depositing throughout } \\
\text { the festival day }\end{array}$ & $\begin{array}{l}\text { Happiness among the children } \\
\text { Saving creates contentment }\end{array}$ & $\begin{array}{l}\text { Playing dices } \\
\text { Happiness among siblings } \\
\text { New-year celebration, girl baby can } \\
\text { wear omaments }\end{array}$ \\
\hline 2 & $\begin{array}{l}\text { Let relax about banking } \\
\text { on celebration day }\end{array}$ & $\begin{array}{l}\text { Enjoy at festival day } \\
\text { Next to the festival day, banks } \\
\text { invites the customers to have } \\
\text { an account }\end{array}$ & $\begin{array}{l}\text { Grant parents and children } \\
\text { relationship } \\
\text { Treating family members }\end{array}$ \\
\hline 3 & $\begin{array}{l}\text { More money incentives } \\
\text { for account holders }\end{array}$ & $\begin{array}{l}\text { To be a smarter lady } \\
\text { Saving more for life security }\end{array}$ & $\begin{array}{l}\text { Not match with the ladies in all } \\
\text { groups in Tamil culture } \\
\text { Reflecting adults age }\end{array}$ \\
\hline 4 & Low cost sales & $\begin{array}{l}\text { Having happiness and } \\
\text { prestigious } \\
\text { More wealth more happiness }\end{array}$ & $\begin{array}{l}\text { Very much with the culture } \\
\text { "AshayaTrithiva" concept match } \\
\text { with the sale }\end{array}$ \\
\hline 5 & $\begin{array}{l}\text { Having } \\
\text { relationship }\end{array}$ & $\begin{array}{l}\text { Flexible payment system } \\
\text { First mover in leasing service } \\
\text { Family security, innovative } \\
\text { service solution }\end{array}$ & $\begin{array}{l}\text { Mother and kid celebrities are not set } \\
\text { with the Tamil culture }\end{array}$ \\
\hline 6 & $\begin{array}{l}\text { Unlimited service offer } \\
\text { Flexible payment system }\end{array}$ & $\begin{array}{l}\text { Really enjoying with flexible } \\
\text { payment, talking with friends } \\
\text { in unlimited package }\end{array}$ & $\begin{array}{l}\text { Parents may have Negative attitude } \\
\text { toward the services } \\
\text { Girl Stands very closed to a boy is } \\
\text { not set with the culture }\end{array}$ \\
\hline 7 & 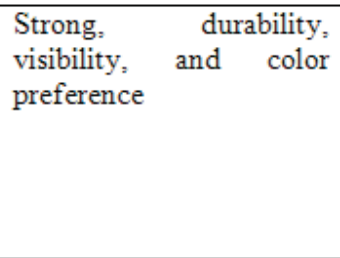 & $\begin{array}{l}\text { Quality of the traditional } \\
\text { roofing sheets }\end{array}$ & $\begin{array}{l}\text { Parent-son traditional relationship } \\
\text { value } \\
\text { Grand parent-grand children } \\
\text { relationship } \\
\text { Admire on carpenter decision } \\
\text { Some of the celebrities are not match } \\
\text { with the culture }\end{array}$ \\
\hline
\end{tabular}




\begin{tabular}{|c|c|c|c|}
\hline 8 & Benefits and free offer & Happiness of home makers & $\begin{array}{l}\text { Traditional food habits } \\
\text { Match with the culture }\end{array}$ \\
\hline 9 & $\begin{array}{l}\text { Nutrition for brain } \\
\text { development } \\
\text { bottle feeding }\end{array}$ & Brain development & $\begin{array}{l}\text { Discourage the Brest feeding } \\
\text { Celebrities not set with the culture }\end{array}$ \\
\hline 10 & $\begin{array}{l}\text { Segmented loan scheme } \\
\text { for MSME development }\end{array}$ & $\begin{array}{l}\text { Different loan scheme for } \\
\text { different segment }\end{array}$ & $\begin{array}{l}\text { Celebrities are not match with the } \\
\text { culture }\end{array}$ \\
\hline 11 & $\begin{array}{l}\text { Succeed women and the } \\
\text { help of the company }\end{array}$ & $\begin{array}{l}\text { Support for financial burden, } \\
\text { achievement with the banks, } \\
\text { and the awards she won }\end{array}$ & Celebrity set with the culture \\
\hline 12 & $\begin{array}{l}\text { Natural sharpness and } \\
\text { great gift to the } \\
\text { consumers } \\
\text { Skin protection }\end{array}$ & $\begin{array}{l}\text { Medical treatment to the } \\
\text { family members } \\
\text { Cleanness and purity in family } \\
\text { movements } \\
\text { Soap creates happiest } \\
\text { movements }\end{array}$ & $\begin{array}{l}\text { Not match with the culture } \\
\text { They express the westem ethos }\end{array}$ \\
\hline 13 & $\begin{array}{l}\text { Extended usage, fastest } \\
\text { sales growth }\end{array}$ & Happiness of home makers & $\begin{array}{l}\text { Set with the culture } \\
\text { Wording in the big fond size give } \\
\text { different meaning, the additional last } \\
\text { letter in Tamil may be deleted. }\end{array}$ \\
\hline 14 & $\begin{array}{l}\text { Three wheelers as a } \\
\text { family vehicle }\end{array}$ & $\begin{array}{l}\text { Family use and income source } \\
\text { Satisfaction with the product } \\
\text { gladness }\end{array}$ & $\begin{array}{l}\text { All the celebrities are traditional with } \\
\text { the culture }\end{array}$ \\
\hline 15 & Special attributes & Experience and trust & Celebrity is set with the culture \\
\hline
\end{tabular}

\section{CONCLUSION}

Celebrity endorsement is an effective advertising method, has great potential to convey message to the customers and consumers. The role played by the celebrity in the advertisement directly impacts on the purchase decision made by the consumers. Whatever the messages they pass through the celebrity endorsement directly and indirectly goes to the customers. Therefore, it is important to make appropriate messages and the similar celebrities assigned with the advertisements. Culture has long been believed to be the force that influences people in a society to follow the norms of their collective identity. culture as transmitted and created content and pattern of values, ideas, and other symbolicmeaningful systems as factors in shaping of human behavior and the artifacts produced through behavior. Culture expresses the way how they live, share values. Tamil culture is special and unique in Sri Lanka, they have a unique lifestyle, food habits, living patterns, family system, and attitudes, a living in North and east Sri Lanka.

Many companies target those Tamil consumers as their special segment. This companies use celebrity endorsement as a strategy to convey message to that target audience. Studies show that celebrity endorsement should set with the culture of the consumers, to whom the advertisements target. This research analyzed 15 celebrity endorsement advertisements, whether they have the cultural set with the Tamil culture, the findings shows that some of them have the cultural identities and some of them have not. Then the study recommends to have 
more cultural value and set with the Tamil cultural identities in celebrity endorsement advertisements to attract the consumers in the Northern Sri Lanka.

\section{LIMITATION OF THE STUDY}

Limited to the time frame the researcher analyzed only 15 advertisements only.

Tamils in Sri Lanka consisted of Tamil speaking Muslims and Tamil speaking Christians, and Tamil speaking Hindus. In this research the researcher considered the Tamil cultural identities as the cultural identities of Tamil speaking Hindu people lone. In future research unique cultural identities of each culture can be analyzed through this methodology.

\section{REFERENCE}

Amir Jafar, PhaniTejAdidam, Musunuri and Rama Prasad (2011) Celebrity endorsements vis-à-vis brand equity of high fashion products: a cross-cultural perspective. Innovative Marketing, Volume 7, Issue 4, 2011

AsmaIqbal, Malik Haqnawaz Danish Maria Raja Tahir, (2014) Exploitation of Women in Beauty Products of "Fair and Lovely": A Critical Discourse Analysis Study. International Journal on Studies in English Language and Literature (IJSELL), Volume 2, Issue 9, September 2014, PP 122-131,ISSN 2347-3126 (Print) \& ISSN 2347-3134
(Online,www.arcjournals. org)

Banks, Michael Y. (1961). "Caste in Jaffna." In Aspects of Caste in South India, Ceylon, and North-West Pakistan, edited by E. R. Leach, 61-77. Cambridge: Cambridge University Press.

Burton, D. (2009) Cross-cultural marketing. New York: Routledge.

Christie, P., Kwon, I., Stoeberl, P. \& Baumhart, R. (2003) A cross-cultural comparison of ethical attitudes of business managers: India, Korea and the United States. Journal of Business Ethics, 46(3), 263-287.

Dissanayake, D.M.R. and Ismail, N. (2015) Relationship between Celebrity Endorsement and Brand Attitude: With Reference to Financial Services Sector Brands in Sri Lanka. 6th International Conference on Business \& Information ICBI 2015, Faculty of Commerce and Management Studies, University of Kelaniya, Sri Lanka.

Elberse, A. and Verleun, J. (2012). The Economic Value of Celebrity Endorsements. Journal of Advertising Research, Volume52, Issue 2, pp. 149165. Retrieved from http:// www.hbs.edu/ faculty/Pages/ item.aspx num=40853on October 12 , 2013

Erdogan, B. Z. (1999). Celebrity 
endorsement: A literature review. Journal of marketing management, 15(4), 291-314.

Fuglerud, Ivind, and Oivind Fuglerud (1999). Life on the Outside: The Tamil Diaspora and Long-Distance Nationalism. London: Pluto Press.

GanganeeChandimaSamaraweera and Chongguang L P and ping Qing (2015), Annual research conference, University of Ruhuna

Hofstede, G., (1980) Culture's consequences: international differences in work-related values. Baverly Hills, CA: Sage Publications.

Kshatriya, G.K. (1995). "Genetic affinities of Sri Lankan populations". Human Biology(American Association of Anthropological Genetics) 67 (6): 84366.

Kroeber, A. L., \& Parsons, T. (1958). The concepts of culture and of social system. American Sociological Review, 23(5), 582-583.

Kress, G \&Leeuwen (1996) Grammar of Visual Design

Kluckhohn, F.R. \&Strodtbeck, F.Z. (1961) Variations in Value Orientations. WestPort, CT: Greenwood Press.
Multimodality, representation and new media. Information Design Journal, 12(2), 110-119.

Langmeyer, L., \& Walker, M. (1991). A first step to identify the meaning in celebrity endorsers. NA-Advances in Consumer Research Volume 18.

Maheshwaran, V (1998) Veera Saivam and Veera Saiva Commnity in Jaffna ", Kumbabisheka Malar, Kokatticholai, Tahanthonreeswara Temple, Baticaloa, 1998.

Markus, H. R., \&Kitayama, S. (1991). Culture and the self: Implications for cognition, emotion, and motivation. Psychological review, 98(2), 224.

McCracken, G. (1989) Who is the celebrity endorser? Cultural foundations of the endorsement process. Journal of Consumer Research, 16(3), 310-321.

Maheshwaran, V (1998) Vaishnava Development in Tamil Nadu up-to Chola Period", Seminar organized by the Department of Hindu Cultural Affairs, Ministry of Cultural Affairs, 1998.

Maheshwaran, V (1998) Discussion on Ealathu Poothan Devanar, Illankathir, Tamil Sangam, University of Peradeniya, 1999.

Maheshwaran, V (1998) "A Study of the Use of Tamil Language in Text Books", 
Seminar on Tamil Education in Sri Lanka, International Tamil Research Institute, Sri Lanka Branch, 1999.

Maheshwaran, V (1998) Pharathy's "Vinayaker Nanmani Malai:, Akilam, Quaterly Journal, Akilam Publication, Kandy, 2000.

Ravindra Dissanayake, D, M, (2015) Factors Determine the Customer-Celebrity Relationship towards Perceived Celebrity Endorsements: Propositions to Hypothesize Future Studies in Sri Lankan Services Sector, Sri Lanka. Journal of Marketing Vol. 01, Issue 02 (July December 2015):22-35

Schwartz, S. H. (1999) A theory of cultural values and some implications for work. Applied Psychology: An International Review, 48(1), 23-47.

Sojka, J. Z. \&Tansuhaj, P. S. (1995) Crosscultural consumer research: A twentyyear review. Advances in Consumer Research, 22(1), 461-474.

Taylor, E. (1964) Culture defined, in L. A. Coser and B. Rosenberg (eds) Sociological theory: A book of readings. West Drayton: CollierMacmillan.

Samaraweera, G. C., \& Ping, Q. Effect of Product Harm Crises on Facets of Consumer Based Brand Equity: Asian Emerging Markets' Perspective.
Tellis, G. J., Golder, P. N., \& Foster, J. A. (2004). Predicting sales takeoff for Whirlpool's new personal valet. Marketing Science, 23(2), 180-191.

Sivesan,S (2013) impact of celebrity endorsement on brand equity in cosmetic product, International journal of advanced research in management and social sciencesissn: 2278-6236, vol. 2 | no. 4 | april 2013 www.garph.co.uk

Thusyanthy, V \&Tharanikaran, V (2015), The Relationship Variables to Celebrity Endorsement and Brand Equity: A Comprehensive Review, International Journal of Business and Management; Vol. 10, No. 11; 2015 ISSN 1833-3850 E-ISSN 1833-8119 Published by Canadian Center of Science and Education.

Tehseem, T and Hameed, a (2015), celebrities endorsement in conflating beauty adverts: a feministic perspective, European Journal of English Language, Linguistics and Literature Vol. 2 No. 2, 2015 ISSN 2059-2027

Zhen Sun (2013) Cultural Values Conveyed Through Celebrity Endorsers: A Content Analysis of Chinese Television Commercials. International Journal of Communication 7 (2013), 2631-2652 19328036/20130005 